Cornell Law Library

Scholarship@Cornell Law: A Digital Repository

Cornell Law Faculty Publications

Faculty Scholarship

$6-2001$

\title{
Restitution and Equity: An Analysis of the Principle of Unjust Enrichment
}

Emily Sherwin

Cornell Law School, els36@cornell.edu

Follow this and additional works at: http://scholarship.law.cornell.edu/facpub

Part of the Contracts Commons, and the Remedies Commons

\section{Recommended Citation}

Sherwin, Emily, "Restitution and Equity: An Analysis of the Principle of Unjust Enrichment" (2001). Cornell Law Faculty Publications. Paper 847.

http://scholarship.law.cornell.edu/facpub/847

This Article is brought to you for free and open access by the Faculty Scholarship at Scholarship@Cornell Law: A Digital Repository. It has been accepted for inclusion in Cornell Law Faculty Publications by an authorized administrator of Scholarship@Cornell Law: A Digital Repository. For more information, please contact jmp8@cornell.edu. 


\title{
Restitution and Equity: An Analysis of the Principle of Unjust Enrichment
}

\author{
Emily Sherwin*
}

The law of restitution, as we know it, was invented in 1937 with the publication of the Restatement of Restitution. The reporters of the Restatement, Warren Seavey and Austin Scott, set out deliberately to create a field of law. To that end, they assembled a variety of doctrinal rulesnot previously linked-which, in their view, were connected by the principle of unjust enrichment. ${ }^{1}$

The principle of unjust enrichment, as expressed in the first section of the Restatement, holds that "[a] person who has been unjustly enriched at the expense of another is required to make restitution to the other." 2 The reporters did not invent the notion of unjust enrichment; it dates at least to Roman law. ${ }^{3}$ But for the most part, prior to the Restatement, English and American courts deciding what we think of as restitution cases did not refer to unjust enrichment.

The Restatement's proposals were widely accepted. Restitution is now acknowledged to be a component of our law, and unjust enrichment is

* Professor of Law, University of San Diego. Thanks to Kevin Clermont, Andrew Kull, Doug Rendleman, and Christopher Wonnell for helpful comments. Thanks also to the Texas Law Review and to all who participated in the Texas Law Review Symposium on Restitution and Unjust Enrichment in January of 2001. The University of San Diego provided generous research support for this Article.

1. For the reporters' explanation of the project, see Warren A. Seavey \& Austin W. Scott, Restitution, 213 LAW Q, REV. 29, 29-32 (1938).

2. RESTATEMENT OF RESTITUTION § 1 (1937) [hereinafter RESTATEMENT]. The next section cuts back significantly on the first by stating an opposing principle: "A person who officiously confers a benefit upon another is not entitled to restitution therefor." Id. $\$ 2$.

3. See, e.g., JOHN P. DAWSON, UNJUST ENRICHMENT: A COMPARATIVE ANALYSIS 42-63 (1951). For discussion of unjust enrichment in civil law, particularly French and German law, see, for example, id. at 63-109; Barry Nicholas, Unjustified Enrichment in the Civil Law and Louisiana Law, 36 TUL. L. REV. 605, 611-46 (1962). Early treatments of unjust enrichment in America appear in WiLLIAM A. KEENER, THE LAW OF QUASI-CONTRACTS 16 (1893) (citing the legal analysis of Justice Field); J.B. Ames, The History of Assumpsit, 2 HARV. L. REV. 53, 66, 69 (1888) (discussing unjust enrichment by early American legal scholars). 
generally understood to be the guiding principle of the field of restitution. ${ }^{4}$ In the Draft Restatement now underway, unjust enrichment not only retains its status as a unifying "general principle," but appears in the title of the work: Restatement (Third) of Restitution and Unjust Enrichment.

This Article is a study of the principle of unjust enrichment and its connection, if any, to "equity." 5 The problem addressed here is not the substantive meaning of unjust enrichment, but the role that unjust enrichment plays in judicial decision making. I will argue that the principle of unjust enrichment can be understood in at least three ways. First, unjust enrichment can be interpreted as a principle of Aristotelian equity, providing correction when normally sound rules produce unjust results in particular cases. Second, unjust enrichment can be characterized as a "legal principle" incorporating a broad ideal of justice, from which courts can deduce solutions to particular restitution problems. Finally, unjust enrichment can be understood simply as expressing a common theme of restitution cases. On this view, unjust enrichment is a descriptive and organizational principle, one which plays no direct role in judicial decision making. It may shape judicial decision making in a general way, but is not a source of authority for particular outcomes. ${ }^{6}$

4. Endorsement of the principle of unjust enrichment is not universal. Professor Dawson, in his later writings, called unjust enrichment an "overworked phrase" and argued that it could not explain important categories of restitution cases. John P. Dawson, Restitution Without Enrichment, 61 B.U. L. REV. 563, 620 (1981) [hereinafter Dawson, Restitution]. For a creative attack on the principle of unjust enrichment, see Christopher T. Wonnell, Replacing the Unity Principle of Unjust Enrichment, 45 EMORY L.J. 153 (1996). Wonnell argues that unjust enrichment is descriptively inaccurate, because most restitution cases are best understood as based on harm rather than gain; that unjust enrichment is meaningless as a decisional standard; and that the idea of relief against unjust enrichment is potentially insidious because it encourages envy and conflicts with the healthy utilitarian attitude that gains are good. Id. at 154-55.

5. RESTATEMENT (THIRD) OF RESTITUTION AND UNJUST ENRICHMENT (Discussion Draft 2000) [hereinafter ALI DRAFT]. As will appear later in this Article, the term "equity" has many meanings for lawyers, some of them vague to the point of obfuscation. It might be best for the clarity of legal analysis if we disposed of the term altogether, or limited it to refer to the actual practice of chancery courts prior to the procedural merger of law and equity. However, the word is so far entrenched in legal usage that banishing it now is surely impossible.

6. Peter Birks has set out an understanding of the principle of unjust enrichment that seems quite similar to the third approach described in the text. See PETER BIRKS, AN INTRODUCTION TO THE LAW OF RESTITUTION 18-25 (1989). I find Birks's arguments persuasive and hope to amplify them in this Article. Hanoch Dagan, writing about contract, also argues powerfully for a modest understanding of the principle of unjust enrichment. See Hanoch Dagan, Restitutionary Damages for Breach of Contract: An Exercise in Private Law Theory, in 1 THEORETICAL INQUIRIES IN LAW 115, 131 (Ariel Porat ed., 2000) (" $[D]$ anger can be avoided by seeing the general principle against unjust enrichment as only a theme of the law of restimution-a framework for arranging and classifying norms that reflect divergent social values;"); see also Andrew Kull, Rationalizing Restitution, 83 CAL. L. REV. 1191, 1196 (1995) (describing unjust enrichment as a unifying theme and a necessary condition for recovery in restitution, but not a standard for decision).

For an analysis of the role of restitution and unjust enrichment in common-law decision making, together with a fascinating account of restitution arguments in tobacco litigation, see Doug Rendleman, 
The first two of these interpretations associate unjust enrichment-and hence the law of restitution-with equity, although they invoke different meanings of the term "equity." The third view does not imply a special affinity between restitution and equity. Instead, restitution is no more or less equitable than other areas of law.

The choice among these different conceptions of the principle of unjust enrichment will have at least a psychological effect both on the process of restating the law of restitution and on judges deciding restitution cases. Moreover, in difficult cases-both those that fall between doctrinal rules and those in which doctrine yields controversial results-the decisional role attributed to the principle of unjust enrichment may be decisive.

This Article begins with a background discussion of unjust enrichment and equity, and two illustrative cases. It then examines the principle of unjust enrichment as a source of authority for judges to do equity in the form of case-by-case exceptions to rules, and concludes that unjust enrichment should not be employed for this purpose. Equity of this kind may be desirable, but it should not be conflated with restitution. Next, this Article describes an alternative approach in which unjust enrichment functions as a legal principle, providing judges with a substantive standard of decision. The final section discusses and endorses the view that unjust enrichment is best understood as a useful organizational principle that does not link restitution to equity in any special way.

\section{Background: Unjust Enrichment and Equity}

Despite wide citation of the principle of unjust enrichment, the nature of the principle is somewhat mysterious. Seavey and Scott described unjust enrichment as a "postulate" underlying the law of restitution, analogous to the postulates underlying tort law (a right against unjust harm) and contract law (a right against breach of promise). ${ }^{7}$ Unjust enrichment was not, in their view, an independent ground for judicial decision making; instead, the operative law of restitution had to be worked out in the form of more specific rules. ${ }^{8}$ Subsequently, however, the principle of unjust enrichment

Common Law Restitution in the Mississippi Tobacco Settlement: Did the Smoke Get in Their Eyes?, 33 GA. L. REV. 847 (1999).

7. Seavey \& Scott, supra note 1 , at $31-32$.

8. Id. at 36-37 ( $[\mathrm{A}] \mathrm{s}$ in other branches of the law, the subject of restitution is not properly or adequately described merely by a description of the purpose or interest which gives life to the rules. It is an organism, growing in accordance with the principle which causes it to exist: a statement of the principle is not a description of what it produces. "). For a similar view, see Edwin W. Patterson, The Scope of Restitution and Unjust Enrichment, 3 MO. L. REV. 223, 231 (1936):

[There is a] distinction . . . between using the principle of unjust enrichment as a classificatory instrument, and using it as an instrument for analysing the facts of a particular case and determining their legal consequences. ... The principle of unjust enrichment will be used deductively, if at all, only in the novel or boundary-line case. 
has sometimes been treated as having a more direct-albeit imperfectly defined-role in the decision of cases. ${ }^{9}$

Closely related to the role of unjust enrichment in judicial decision making is the question whether restitution is equitable in character. Although quasi-contract remedies, from which much of restitution law developed, were historically granted by law courts rather than equity

Even there it will be used as a general test of the propriety of extending the law to include new obligations to make restitution, and will be restricted in application by the absence of analogous precedents."

9. Comments by subsequent restitution scholars about the principle of unjust enrichment and its effect on decision making have been varied and sometimes ambiguous. John Dawson, in his 1951 book Unjust Enrichment, characterized unjust enrichment as "both an aspiration and a standard for judgment," although he also cautioned that unjust enrichment was too broad to be treated as a rule of law, and could never be fully realized in judicial decisions. See DAwSON, supra note 3, at 4-5, 7-8, 24-26; cf. Dawson, Restitution, supra note 4 (arguing that unjust enrichment is not a sufficient explanation for restintion doctrine). Stewart Macaulay, writing in 1959, suggested that the field of restitution, with its guiding principle of unjust enrichment, is distinguishable from other areas of law by an unusual degree of flexibility and judicial discretion. As a consequence, it raises jurisprudential questions about "the tension between decision based on rule and decision based on reaction to individual cases." Stewart Macaulay, Comment, Restitution in Context, 107 U. PA. L. REV. 1133, 1134 (1959). Barry Nicholas wrote in 1962 that unjust enrichment serves as a corrective to rules of law and as a gap-filler when rules fail. However, he also cautioned that the principle should apply only when established rules are not directed to the problem at hand, or are merely "formal" rules. Barry Nicholas, Unjustified Enrichment in the Civil Law and Louisiana Law, 36 TUL. L. REv. 605, 607-10 (1962). George Palmer, in his 1978 treatise on restitution, was somewhat oblique in regard to the nature of the principle of unjust enrichment. He stated that ${ }^{\text {" }}$ u]njust enrichment is an indefinable idea in the same way that justice is an indefinable idea," but concluded that "[ $t]$ his wide and imprecise idea has played a creative role in the development of an important branch of substantive law." 1 GEORGE E. PALMER, THE LAW OF RESTITUTION $\$ 1.1$, at 5 (1978). More recently, Dan Dobbs commented in his treatise on remedies that unjust enrichment is "the fundamental substantive basis for restitution," and "has potential for resolving new problems in striking ways." Yet he went on to state that unjust enrichment is limited in that "it refers to corrective justice, not distributive justice," and "some common patterns in the cases show that the unjust enrichment rationale is often only a unifying generalization about familiar kinds of cases.” 1 DAN B. DOBBS, LAW OF REMEDIES $\S 4.1(2)$, at 557-58 (2d ed. 1993).

Several English scholars appear to favor treating unjust enrichment as a decisional standard. Robert Goff and Gareth Jones, in their restitution treatise, characterize unjust enrichment as a "principle of justice which the law recognizes and gives effect to in a wide variety of claims," and quote Dawson's formulation, that unjust enrichment is "both an aspiration and a standard for judgment." LORD GOFF OF CHIEVELEY \& GARETH JONES, THE LAW OF RESTITUTION 12 (Gareth Jones ed., 5th ed. 1998). See also Robert Goff, Appendix: The Search for Principle, in THE SEARCH FOR PRINCIPLE 313, 324 (William Swadling \& Garech Jones eds., 1999) ("I see the law of restitution gradually developing towards the acceptance of a fully fledged principle of unjust enrichment ... with the emphasis changing from the identification of specific heads of recovery to the identification and closer definition of the limits to a generalized right of recovery."). Jack Beatson commends those jurisdictions that have accepted "unjust enrichment as an independent source of obligation." J. BEATSON, THE USE AND ABUSE OF UNJUST ENRICHMENT 1-2 (1991) [hereinafter BEATSON, USE AND ABUSE]. He also has gone so far as to consider (with reservations) the possibility of legislative enactment of the principle of unjust enrichment. Jack Beatson, Should There Be Legislative Development of the Law of Restitution?, in ESSAYS ON THE LAW OF RESTITUTION 279 (Andrew Burrows ed., 1991) [hereinafter Beatson, Legislative Development]. Peter Birks, in contrast, resists treating unjust enrichment as anything more than an organizing principle for restitution. BIRKS, supra note 6, at 18-25. 
courts, restitution and unjust enrichment have often been associated with equity in a broader sense. The Roman jurist Pomponious wrote that "this by nature is equitable, that no one be made richer by another's loss." 10 In eighteenth century England, Lord Mansfield, who was known for his expansive use of general assumpsit to grant relief we would now classify as restitution, explained that "the gist of this kind of action is, that the defendant, upon the circumstances of the case, is obliged by the ties of natural justice and equity to refund the money." antecedents, courts and scholars often simply assume that unjust enrichment is in some sense an "equitable" principle. ${ }^{12}$

The connection among restitution, unjust enrichment, and equity may prove to be a source of some controversy in discussions of the new Restatement. ${ }^{13}$ The current $A L I$ Draft takes a somewhat delphic stand on the nature of the principle of unjust enrichment. Comments to the introductory sections of the new Restatement deny any intention "to repudiate the traditional, equitable explanation of restitution liability." 14 Yet they

10. This translation comes from Professor Dawson. DAwSON, supra note 3, at 3 .

11. Moses v. Macferlan, 2 Burr. 1005, 1010, 97 Eng. Rep. 676, 681 (K.B. 1760). See DAwSON, supra note 3, at 11-15 (discussing Moses $v$. Macferlan).

12. See Pyeatte v. Pyeatte, 661 P.2d 196, 202-07 (Ariz. App. 1982) (holding a wife's quantum meruit claim for the value of her husband's legal education supported an "equitable award of restitution on the basis of unjust enrichment"); Kistler v. Stoddard, 688 S.W.2d 746, 747 (Ark. App. 1985) (explaining that in permitting a lessee to recover the value of crops after the termination of a lease, notice is taken that "[t]he doctrine is an equitable one"); Kossian v. Am. Nat'l Ins. Co., 254 Cal. App. 2d 647, 651 (1967) (holding that a contractor could recover amount of insurance collected by mortgagee based on the "equitable doctrine of unjust enrichment"); Beacon Homes, Inc. v. Holt, 146 S.E.2d 434, 469 (N.C. 1966) (ruling that the retention of a house mistakenly built on defendant's property was “against equity and good conscience"); Allgood v. Wilmington Sav. \& Trust Co., 88 S.E.2d 825,829 (N.C. 1955) (finding actions for money had and received are "allowed upon the equitable principle that a person should not be permitted to enrich himself at the expense of another"); ALI DRAFT, supra note $5, \S 1 \mathrm{cmt}$. c (referring to "the traditional equitable explanation of restitution liability"); 1 DOBBS, supra note $9, \S 4.1(1)$, at 556 ("courts applying substantive equity and courts applying the law of unjust enrichment are both applying a law of 'good conscience'"); Ames, supra note 3 , at 66 (stating that unjust enrichment is "[t]he equitable principle which lies at the foundation of the great bulk of quasi-contracts"); Edward T. Bishop, Money Had and Received, an Equitable Action at Law, 7 S. CAL. L. REV. 41 (1933) (citing cases referring to the action for money had and received as equitable). See also Doug RENDLEMAN, CASES AND MATERIALS ON REMEDIES 327-28 (6th ed. 1995) (noting that "courts and commentators frequently refer to quasi-contractual restitution as "equitable" but that the multiple meanings of the word "equitable" breed confusion).

13. The author is a member of the American Law Institute Advisory Committee for the Restatement (Third) of Restitution and Unjust Enrichment. Views expressed in this Article, however, are the author's alone, and should not be attributed to the American Law Institute, the Advisory Committee, or the Reporter.

14. ALI DRAFT, supra note 5. At a meeting of the American Law Institute, the Reporter, Andrew Kull, appeared to favor compromise:

I would like ... to write a treatment here that satisfies both the people who are very comfortable talking about equity and good conscience and the people who are decidedly uncomfortable talking about equity and good conscience, because I think we can show both sets of people that the results are the same . . . . 
note that "the purely equitable account of the subject is open to substantial objections. Saying that liability in restitution is imposed to avoid unjust enrichment effectively postpones the real work of definition, leaving to a separate inquiry the question whether a particular transaction is productive of unjust enrichment or not." 15 The comments also propose that restitution is not concerned with unjust enrichment in a "broad sense, but with a narrower set of circumstances giving rise to what is more appropriately called unjustified enrichment . . . . Unjustified enrichment is enrichment that lacks an adequate legal basis . . . ."16

Although formal consideration of the introductory sections of the new Restatement has been deferred until the body of the work is complete, ${ }^{17}$ participants have expressed differing views on the first principles of restitution. Some take the position, originally suggested by Seavey and Scott, that restitution is a body of legal rules in which recovery is commonly based on unjust enrichment, but that unjust enrichment serves as a postulate rather than a standard for decision. ${ }^{18}$ Others find this view inadequate, and insist that the principle of unjust enrichment imparts a special equitable character to the law of restitution. ${ }^{19}$

Equity, of course, is a term with several meanings. It can refer to individuation of justice and overriding of rules; it can refer more generally

2000 PROCEedings OF THE AMERICAN LAW INSTITUTE 240 (May 17, 2000) [hereinafter 2000 PROCEEDINGS] (remarks of Andrew Kull). Because I believe the different possible interpretations of the principle of unjust enrichment have very different implications for judicial decision making, I question whether such a compromise is possible.

15. See ALI DRAFT, supra note $5, \S 1 \mathrm{cmt}$. b.

16. Id. The comments suggest that unjustified enrichment is a preferable term because it steers courts away from direct reliance on vague "standards of equitable and conscientious" behavior, and focuses their attention on the absence of legal ground for the defendant's receipt or retention of value. Id.

17. See 2000 PROCEEDINGS, supra note 14, at 236 (remarks of Andrew Kull) (discussing the order of presentation of tentative drafts).

18. ALI DRAFT, supra note $5, \S 1 \mathrm{cmt}$. b.

19. This position was nicely captured in comments made by Professor Peter Linzer at the American Law Institute's 2000 annual meeting:

[T]t seems to me that restitution is ultimately the law's device for filling the cracks . . . , and what I am concerned about is your statement, at one point, that the question of unjustified enrichment is "not moral but legal". . . . It seems to me you are working very hard to avoid faimess as the sort of guiding concept because it is so unbounded, and I understand that, but I think that that is the essential problem, that we have a tension that has gone on for 250 years between Lord Mansfield saying, "obliged by the ties of natural justice and equity" . . . and those who would have rules ....

2000 ProceEDINGS, supra note 14, at"237 (remarks of Peter Linzer). Professor Linzer apparently would include within the concept of restitution a "relational" analysis of informal dealings and transactions, in which courts arrive at "rough justice" by considering what understandings and assumptions may have arisen between parties and dividing the fruits or losses of the relationship accordingly. See Peter Linzer, Rough Justice: A Theory of Restitution, Reliance, and Implied-In-Fact Contracts (unpublished manuscript, on file with the Texas Law Review). 
to what is morally fair; or it can refer to the rules and practice of English and American courts of equity. This leaves uncertain just what it means to say that unjust enrichment is a principle of equity or that restitution is equitable in nature.

In fact, most restitution cases can be fit without much difficulty into the comparatively concrete doctrinal categories described in the body of the first Restatement: payments induced by fraud, mistake, or coercion; contribution among tortfeasors; unsolicited benefits; unwinding of failed contracts; disgorgement of tortious profits; and fiduciary misconduct. At the same time, there are restitution cases that resist doctrinal classification and can be understood as instances of equitable decision making in various senses of the term. Two examples follow; both will reappear in later discussions to illustrate different conceptions of unjust enrichment.

The first case for consideration is Kossian v. American National Insurance $\mathrm{Co}^{20}$ The plaintiff in Kossian was hired by the owner of a hotel to clean up debris after a fire. He performed the work but was never paid. Later, the hotel owner filed a bankruptcy petition. The trustee in bankruptcy abandoned the hotel to the defendant company, which held a mortgage on the property. The defendant took possession of the debrisfree premises, and also collected on an insurance policy the hotel owner had maintained for the defendant's benefit pursuant to the mortgage. The insurance contract indemnified the defendant for fire loss, including the cost of removing debris; but, like most insurance contracts, it did not require that the work be done.

The plaintiff asserted a restitution claim against the defendant, seeking a money remedy in the amount of the insurance proceeds corresponding to debris removal. ${ }^{21}$ Although the defendant never requested the plaintiff's services, and the insurance payment was based on an independent contract between the hotel owner and the insurer, the court allowed the claim. ${ }^{22}$ It interpreted the "equitable doctrine of unjust enrichment" to mean that the defendant should not "be indemnified twice for the same loss, once in labor and materials and again in money, to the detriment (forfeiture) of the party who furnished the labor and materials."23

The second sample case is Sharp v. Kosmalski. ${ }^{24}$ In this case, the plaintiff was a fifty-six-year-old farmer; the defendant was a forty-year-old female schoolteacher who became his companion and cohabitant after the death of his wife. The plaintiff courted the defendant over a period of

20. 254 Cal. App. 2 d 647 (1967).

21. Id. at 649 .

22. Id.

23. Id. at 651 .

24. 351 N.E.2d 721 (1976). 
several years, but the defendant consistently refused his marriage proposals. In an effort to persuade her, the plaintiff gave the defendant numerous gifts, culminating in a gift of his principal asset, the farm. Ultimately the two split up, and the defendant evicted the plaintiff from the farm..$^{25}$

The plaintiff then sued, seeking a constructive trust remedy that would restore his title to the farm. ${ }^{26}$ The New York Court of Appeals reversed an adverse trial court decision and remanded for consideration of the plaintiff's claim. ${ }^{27}$ In the view of the Court of Appeals, the "purpose of the constructive trust remedy is to prevent unjust enrichment," and the existence of unjust enrichment is determined "through the application of the principles of equity." 28 Accordingly, rather than try to assimilate the case to the doctrine of undue influence, the court simply determined that an unjust enrichment had occurred. ${ }^{29}$ The facts, it said, presented "the classic example of a situation where equity should intervene to scrutinize a transaction pregnant with opportunity for abuse and unfairness." 30

Both Kossian and Sharp refer to the principle of unjust enrichment as a principle of equity, and invoke it in support of novel, possibly controversial results. ${ }^{31}$ Neither court, however, explained just what sense of equity it had in mind. In the following sections, I will attempt to identify more precisely what different types of judicial reasoning, equitable and otherwise, might be entailed by different interpretations of the principle of unjust enrichment.

25. Id. at 723 .

26. Id. at 722 .

27. Id. at 724 .

28. Id.

29. Id.

30. Id. The court explained further that prior cases of this type established four requirements for a constructive trust: "(1) a confidential or fiduciary relation, (2) a promise, (3) a transfer in reliance thereon and (4) unjust enrichment." Id. at 723. However, the court was quite free with these supposed doctrinal requirements. The confidential relation was an informal one, inferred from the plaintiff's dependence on the defendant, and in any event, was not sufficient in itself to support recovery. Id. The promise, and the plaintiff's reliance on it, were "implied or inferred from the very transaction itself." Id. Thus, the real basis of the decision was the court's indeterminate conclusion that the defendant was unjustly enriched.

31. In Kossian, the court noted that no like cases had been cited by the plaintiff. Kossian may not have been a true novelty. Section 46 of the pending Restatement (Third) of Restitution and Unjust Enrichment discusses a handful of arguably similar cases. ALI DRAFT, supra note 5, $\S 46$. However, there is little question that the Califomia Court of Appeals believed it was facing a situation not covered by precedent, and hence deciding by direct reference to the principle of unjust enrichment. Kossian v. Am. Nat'l Ins. Co., 254 Cal. App. 2d 647, 650 (1967). In Sharp, a three-member dissent argued that the decision was without doctrinal support and that "the appellant knowingly and voluntarily conveyed his property without agreement or condition of any kind, express or implied, and with full knowledge of their legal effect." Sharp, 351 N.E.2d at 724-25. 
II. Three Conceptions of the Principle of Unjust Enrichment

A. Unjust Enrichment As Authority for Equitable Discretion in Particular Cases

Aristotle defined equity as a correction of law when it falls into error as a result of its generality. ${ }^{32}$ Thus, one sense of equity is individualized justice, adjusting the outcomes of general rules when their application to particular cases produces results that are too harsh or are contrary to the underlying objectives of the rules. The function of equity in this sense is not to overrule unjust rules, but to correct unjust applications of rules that may, as a general matter, be just and desirable rules.

A brief discussion of the advantages and disadvantages of rules may help to clarify this form of equity. Laws presumably are designed to promote certain practical and moral ends. Casting law in the form of rules, rather than simply instructing actors to pursue the desired ends, serves to settle controversy and uncertainty. Rules also can minimize errors, by imparting information to nonexpert actors or by coordinating the conduct of actors who otherwise would not know what to expect of each other. $^{33}$ Therefore, even if the rule-making authority and its subjects agree on ends, actors may conform better to those ends by following the authority's rules than they would by following their own best judgment. ${ }^{34}$

The need for equity arises because rules produce errors of their own. A rule, in order to serve the purposes of settling disputes-providing expert guidance and coordinating conduct-must be determinate and general. It

32. ARISTOTLE, NicOMACHEAN ETHICS $1138 \mathrm{~b} 25$ (Terence Irwin trans., Hackett Publ'g Co. 1985) (circa 350 B.C.) ("And this is the nature of what is decent-rectification of law in so far as the universality of law makes it deficient.")

33. For general analysis of the function of rules in avoiding errors, see JOSEPH RAZ, THE MORALITY OF FREEDOM 70-80 (1986) (noting that the practical authority of law leads people to act more successfully for the reasons that apply to them); FREDERICK SCHAUER, PLAYING BY THE RULES: A PHILOSOPHICAL EXAMINATION OF RULE-BASED DECISION-MAKING IN LAW AND IN LIFE 149-55 (1991) (commenting upon the duality of error and highlighting those errors "that arise from an incorrect application of a theoretically optimizing particularistic decision-making procedure.”).

For sources recognizing the function of rules in providing expert guidance, see, e.g., TOM CAMPBELl, THE LEGAL THEORY OF ETHICAL POSITIVISM 53-54 (1996); SCHAUER, supra at 150-52, 158-59; Jules L. Coleman, Authority and Reason, in THE AUTONOMY OF LAW 287, 305 (Robert P. George ed., 1996).

On the coordination function of rules, see, for example, RAZ, supra at 49-50; SCHAUER, supra at 163-66; Gerald J. Postema, Coordination and Convention at the Foundations of Law, $11 \mathrm{~J}$. LEGAL STUD. 165, 172-86; Donald H. Regan, Authority and Value: Reflections on Raz's Morality of Freedom, 62 S. CAL. L. REV. 995, 1006-10 (1989).

34. See RAZ, supra note 33, at 70-80 (discussing the "normal justification" of rules); SCHAUER, supra note 33, at 149-55; Larry Alexander, Pursuing the Good-Indirectly, 95 ETHICs 315 (1985); Coleman, supra note 33, at 304-05. For a more detailed analysis of benefits of rules, as well as the paradox they create, see LARRY ALEXANDER \& EMILY SHERWIN, THE RULE OF RULES: RULES, PRINCIPLES, AND DILEMMAS OF LAW, ch. 4 (forthcoming 2001) (manuscript on file with the Texas Law Review). 
must be phrased in terms that are more concrete than the ends it is designed to promote, so that actors can understand what it requires; it must cover classes of cases; and it must continue in effect over a period of time in which circumstances may change. ${ }^{35}$ Therefore, because the rule is not identical to the broader ends it serves, the rule will sometimes result in mistakes-it will require outcomes that do not promote, and may frustrate, the desired ends. In other words, even the best possible rules will be imperfect in some of their applications. ${ }^{36}$

Of course, judges can also make mistakes when they engage in equitable correction of the results of rules. A judge who rejects the outcome required by a rule, believing it is not the best outcome for the case at hand, may be wrong. ${ }^{37}$ Thus, it may be that overall, fewer errors will occur if actors and judges follow the rules in all cases than if judges make particularized exceptions to rules. Nevertheless, the impulse to make exceptions when rules appear to produce the wrong result is very strong. It is hard to imagine that a legal system administered by rational judges could flatly renounce this form of equity. ${ }^{38}$

In early English law, the corrective role was assumed by the Chancery Court, which became known as the Court of Equity. ${ }^{39}$ By the fourteenth century, common-law forms of action were well established and the law was becoming increasingly rigid. ${ }^{40}$ The King's Chancellors began to hear and grant petitions for special relief, first in response to failures of procedural justice, such as bribery of jurors, and later in response to more substantive forms of unfairness, such as fraud, mistake, and overreaching. ${ }^{41}$

35. See SCHAUER, supra note 33, at 54 (claiming rules are “instantiations” of background principles).

36. See id. at 31-34, 47-52 (discussing under-inclusiveness and over-inclusiveness).

37. In addition to simple miscalculation of what the actor should have done, a judge may lose sight of the effect that a lenient decision will have on the coordination power of the rule. If rules are known to be subject to judicial exceptions, actors have less reason to follow them or to believe that others will follow them. On the exemplary effect of leniency or punishment on reasoning, see ALEXANDER \& SHERWIN, supra note 34, at 4-43 to 4-44; HEIDI M. HURD, MORAL COMBAT 190-93, 217-21 (1999) [hereinafter HURD, MORAL COMBAT]; Heidi M. Hurd, Justifiably Punishing the Justified, 90 MiCH. L. REV. 2203, 2293-2301 (1992).

38. See HURD, MORAL COMBAT, supra note 37, at 69-94; Heidi M. Hurd, Challenging Authority, 100 YALE L.J. 1611 (1991) [hereinafter Hurd, Challenging Authority] (rejecting the "practical authority" of legal rules because rationality requires that we "act on the balance of reasons available to us").

39. Helpful discussions of the history of equity can be found in J.H. BAKER, AN INTRODUCTION TO ENGLISH LEGAL HisTORY 112-33 (3d ed. 1990), and F.W. MAITLAND, EQUITY: A COURSE OF LECTURES (A.H. Chaytor \& W.J. Whittaker eds., 1936). For a concise account with illustrations, see RICHARD H. FIELD ET AL., CIVIL PROCEDURE 69-77 (7th ed. Supp. 2000). Separate equity courts also were established in the United States, with procedures varying from state to state. See, e.g., id. at 94 (reviewing the evolution of American equity).

40. See BAKER, supra note 39, at 65-67 (describing the closing of the register of writs in the thirteenth century); see also id. at 118 (describing the rigors of the common law).

41. See id. at 117-18; MAILAND, supra note 39, at 4-5. 
For a number of reasons, the decisions of the early Chancellors were individualized and fact-dependent. ${ }^{42}$ Chancery was not initially recognized as a court. Chancery cases were initiated by means of descriptive "bills" rather than formulary writs; the Chancellors investigated facts by means of interrogation, and fact-finding continued until the Chancellor was satisfied with the data. ${ }^{43}$ Until the sixteenth century, there were no Chancery reports and hence no precedents to follow. ${ }^{44}$ Most importantly, the Chancellors avoided direct conflict between their decisions and the rules established by the law courts. At least in theory, a Chancery decree did not alter legal entitlements, but acted instead on the person and "conscience" of the defendant, ordering him to do what the Chancellor felt was just, notwithstanding his legal rights. ${ }^{45}$

Even the Court of Equity did not maintain a practice of pure equity. There were objections to the Chancellors' discretionary form of justice, and Chancery practice soon became more settled. The Chancellors developed areas of expertise, such as uses and trusts, in which decisions conformed to established principles and sometimes to fixed rules. ${ }^{46}$ By the nineteenth century, when law and equity began to merge procedurally, the common law had matured and grown more responsive to changing circumstances, and Chancery no longer performed its original equitable function. ${ }^{47}$ Yet for a period of time, when the common law was at its most inflexible, Chancery served to ameliorate the effects of strict rules in particular cases.

The idea now under consideration is that the principle of unjust enrichment should be interpreted as a source of authority for Aristotelian

42. Baker describes the comparatively informal procedures of early Chancery, the Chancellors' concern with individual cases, and their lack of concern for distinctions between fact and law. BAKER, supra note 39 , at $119-20,122-24$.

43. For descriptions of Chancery procedure, see id. at 119-20; MAITLAND, supra note 39, at 4-5.

44. See BAKER, supra note 39, at 127; MAITLAND, supra note 39 , at 8 .

45. An equity decree did not alter either legal titles or prior legal judgments, although it might order the defendant not to enforce his title or judgment. If the defendant disobeyed, the Chancellor could hold him in contempt and jail him until he obeyed. This rendered the defendant's legal rights practically unimportant. See, e.g., J.R. v. M.P., Y.B. 37 Henry 6, 13, pl.3 (1459) (translated and condensed in ZECHARIAH CHAFEE, JR. \& EDWARD D. RE, CASES AND MATERIALS ON EQUITY 26 (5th ed. 1967)) (upholding the validity of a note following an equity decree enjoining the holder from enforcing it); Earl of Oxford's Case, 21 Eng. Rep. 485, 487 (Ch. 1615) ("WW]hen a judgment is obtained by Oppression, Wrong and a hard Conscience, the Chancellor will frustrate and set it aside, not for any error or Defect in the judgment, but for the hard Conscience of the Party."); MAITLAND, supra note 39, at 9 ("You in breach of trust have obtained a judgment-the Chancellor does not say that this judgment was wrongly granted, he does not annul it, he tells you that for reasons personal to yourself it will be inequitable for you to enforce that judgment, and that you are not to enforce it.").

46. Baker and Maitland describe the sixteenth-century reaction to the Chancellors' discretionary justice and the gradual settling of equity practice. BAKER, supra note 39, at 123-24, 126-28; MAITLAND, supra note 39 , at 7-10.

47. For an account of reforms in common-law procedure and of the corruption and procedural quagmire that eventually beset the Chancery, see BAKER, supra note 39, at 47-56, 128-30. 
equity in modern law. In other words, unjust enrichment should be understood as a principle of individualized, fact-specific decision making, capable of overriding otherwise applicable rules. On this view of unjust enrichment, Kossian v. American National Insurance Co.-the case of the unpaid debris-sweeper-could be seen as a case in which rules requiring privity as a condition of contract liability and rules governing entitlement to insurance proceeds produced what the court felt to be an unjust result in unusual circumstances. ${ }^{48}$ Similarly, Sharp v. Kosmalski-the case of the jilted farmer-could be seen as a case in which the rules governing finality of gifts produced what the court felt to be an unjust result in circumstances not covered by other equitable doctrines such as undue influence. ${ }^{49}$ If unjust enrichment is understood in this way, neither decision implies that the legal rules at issue were misguided or obsolete rules. Rather, the principle of unjust enrichment gives judges power to disregard rules when, as a result of their generality, they produce bad results.

This conception of unjust enrichment, as a principle calling for individualized justice, is to some extent a natural continuation of the history of restitution. Restitution at law developed primarily through the form of action known as assumpsit, ${ }^{50}$ and particularly under the common counts of general assumpsit. The pleadings in early restitution cases typically alleged that the defendant had requested payment, goods, or services, and had promised to pay. ${ }^{51}$ From an early time, however, courts allowed recovery without proof of an actual request or an actual promise to pay. ${ }^{52}$ By the end of the seventeenth century both the request and the promise could be implied by law, allowing recovery for mistaken payment or for proceeds of property wrongfully taken, although no sort of bargain was involved..$^{53}$ Thus, not only were the formal legal requirements for these "quasi-contract" claims much simpler than the requirements for other actions, but such requirements as there were, were acknowledged to be fictitious. As a result, quasi-contract decisions were highly fact-dependent

48. See supra text accompanying notes $20-23$.

49. See supra text accompanying notes 24-28. Undue influence is itself a highly fact-specific doctrine. However, courts have given undue influence at least some rough doctrinal contours, which did not easily encompass the facts of Sharp v. Kosmalski, 351 N.E. 2d 721 (1976). Hence, the court turned directly to unjust enrichment.

50. See generally BAKER, supra note 39, at 409-26; J.H. Baker, The History of Quasi-Contract in English Law, in RESTITUTION: PAST, PRESENT AND FUTURE 37 (W.R. Cornish et al. eds., 1998) [hereinafter Baker, History of Quasi-Contract]. Baker describes three types of assumpsit used from the seventeenth century onward for claims we would view as restitution claims: quantum meruit for the value of services, quantum valebant for the value of goods, and indebitatus assumpsit, which resolved into a variety of "common counts," such as the count for money had and received. Id. at 41-53.

51. See BAKER, supra note 39, at 410-12.

52. See id. at $415-16$.

53. See id. at 42-52 (discussing the development of fictions). 
and courts were free to engage in an individualized assessment of claims. $^{54}$

Restitution, as assembled in the first Restatement, also encompassed not only quasi-contract, but also the remedy known as the constructive trust. ${ }^{55}$ Constructive trusts evolved in Chancery, where decision making tended to be fact-specific. ${ }^{56}$ Moreover, the fiduciary relation between defendant and plaintiff is often pure fiction, as when a thief is deemed to hold the proceeds of stolen goods on constructive trust. ${ }^{57}$ As in the case of quasi-contract, the fictitious basis of the claim resulted in an emphasis on particular facts. ${ }^{58}$

There are two ways in which a principle of unjust enrichment embodying Aristotelian equity might be implemented. First, "unjust enrichment" could be understood as a direction to courts to engage in particularized, discretionary decision making within the doctrinal field of restitution, however that field might be defined. In other words, restitution would constitute a special domain for equitable intervention. Second, "unjust enrichment" could be seen as a more general authorization for courts to depart from legal rules when the rules produce unjust results-an authorization that would cut across the substantive fields of private law.

1. Equity Within a Limited Domain.-The first of the variations just mentioned authorizes individualized decision making within a restricted area of law. On this view, the principle of unjust enrichment implies that when faced with a problem of restitution, courts should feel particularly free to depart from rules when the rules produce harsh results in particular cases. They should scrutinize the outcomes of otherwise applicable rules more carefully than they might in other areas of law, and reject results that seem harsh or contrary to the perceived objectives of the rules.

A similar but somewhat more radical idea is that within the field of restitution, rules simply should not apply. Instead, courts should have full

54. Baker relates that long after the central English courts sitting at Westminster had begun to review factual records in most types of cases, and hence to develop substantive rules of law, quasicontract claims based on the common counts were still viewed as matters of trial practice, not to be scrutinized. Therefore "quasi-contract would continue for many years to be regarded as part of the learning of circuit practice rather than of speculative jurisprudence." Id. at 55.

55. RESTATEMENT, supra note $2, \S 160$ (defining constructive trusts).

56. See text accompanying notes $42-44$.

57. Constructive trusts originally were remedies for fiduciary misconduct. In the nineteenth century, however, American courts extended the scope of the remedy to include wrongful acquisitions of property, in which the defendant is not a fiduciary but a thief. See DAWSON, supra note 3, at 27-28. See also RESTATEMENT, supra note 2, §\$166-69 (delineating when a constructive trust arises based on a wrong done by one party to another, including situations such as: fraud by a transferee to a transferor, fraud by a third person to a transferor, fraud by a transferor to a third person, and fraud by a transferee to a third person).

58. See, e.g., Beatty v. Guggenheim Exploration Co., 122 N.E. 378 (N.Y. 1959) (stating that "[a] constructive trust is the formula through which the conscience of equity finds expression"). 
discretion to decide as they deem best. Along these lines, Stewart Macaulay once suggested that, in deciding restitution cases, courts should act in the manner of administrative agencies, with "power to base decisions on unexplained expertise." 59

An approach of this kind, however, requires some justification-some reason why individualized justice is particularly appropriate to restitutionas opposed to tort or contract. The question of when courts should make individualized exceptions to rules is a question of how effective the rules are in avoiding error and how much damage will be done by undefined exceptions. ${ }^{60}$ It follows that courts are justified in treating restitution as a domain for equity in the sense of adjustments to rules in particular cases if and only if rules are particularly unreliable, and exceptions to rules are particularly benign, both within the field of restitution and throughout the field of restitution law. The analysis that follows indicates that this is not the case.

Of course, before any conclusion can be reached on this question, it is necessary to define the field of restitution. Any definition is sure to be controversial-for example, commentators have disagreed about whether unjust enrichment is a necessary element of restitution. ${ }^{61}$ Two likely possibilities are discussed below; in each case, no obvious correlation appears between restitution and a special need for individualized justice.

One way to define the field of restitution is to include within it those subject matter categories that have been conventionally classified under the heading of restitution in textbooks, judicial opinions, and the Restatementcategories such as fraud, mistake, coercion, unenforceable contracts, and fiduciary misconduct. ${ }^{2}$ The question then arises whether there is anything in the nature of these subjects that makes them especially good

59. Macaulay, supra note 9 , at 1135.

60. See supra notes 33-38.

61. Compare Dawson, Restitution, supra note 4 (arguing that restitution encompasses many cases in which the defendant is not enriched, as when failed contracts are unwound and losses allocated between parties), with Kull, supra note 6, at 1197, 1199-1212 (positing that unjust enrichment cases account for most of restitution law and thus that Dawson's discussion of "restitution without enrichment" is not restitution at all), and GOFF \& JONES, supra note 9, at 3 (equating restitution and unjust enrichment).

62. In addition to the Restatement, several well-known treatises provide comprehensive summaries of restitution doctrine. See GoFF \& JONES, supra note 9; PALMER, supra note 9.

A preliminary difficulty with a doctrinal definition of the field of restitution is that the doctrinal categories set out in the Restatement and restitution treatises overlap substantively with rules of tort and contract. Thus, the set of cases in which restitution is the sole ground of recovery is smaller than the set of all cases that might be classed as restitution cases, based on unjust enrichment. Compare Douglas Laycock, The Scope and Significance of Restitution, 67 TEXAS L. REV. 1277 (1989) (distinguishing between restitution as a source of liability and restitution as a form of remedy), with Kull, supra note 6, at 1225 (characterizing gain-based recoveries for tortious harms or breaches of contract as instances of substantive restitution based on unjust enrichment). I will assume a broader definition including claims that might also be recoverable in tort or contract. This assumption, however, does not alter my conclusions. 
subjects for judicial authority to vary the outcomes of rules on a case-bycase basis.

It is sometimes said that decision making in the conventionally defined field of restitution should be fact-specific because restitution encompasses a great variety of situations. ${ }^{63}$ Another way to put this is that within the field of restitution, lack of information about future cases makes rules unreliable. Rule makers, including judges in prior cases, cannot accurately predict the range of cases that will fall within the terms of their rules; therefore courts should be skeptical of rules as they decide individual cases. The problem of how to anticipate the future effects of general rules, however, is common to all rules, and there is no obvious reason to believe that the conventional subject matter of restitution is more varied than the subject matter of tort or contract. All involve a wide range of human motives, actions, and responses.

Another possible argument for individualized decision making in the conventionally defined field of restitution is that the coordination benefits of rules-the benefits that come from knowing what to expect from others and from the legal system-are less important here than in other areas of law. ${ }^{64}$ This argument may have merit in some cases of mistake: by definition, actors laboring under a mistake are unaware of the facts that would allow them to make use of rules to coordinate their conduct with the conduct of others. Yet, in transactions involving reasonably sophisticated parties, mistake itself may be a contingency for which plans are made, through precautions or contractual allocations of risk. ${ }^{65}$ Moreover, not

63. See Macaulay, supra note 9, at 1136 (finding individualized decisionmaking desirable because it is too difficult to "crystallize wise solutions for all cases" in the areas of fraud, mistake, duress, and fiduciary duty).

64. See RAZ, supra note 33, at 49-50; SCHAUER, supra note 33, at 163-66; Postema, supra note 33, at 172-86; Regan, supra note 33, at 1006-10. In the American Law Institute proceedings, the Reporter for the Restatement (Third) of Restitution and Unjust Enrichment remarked that a characteristic feature of restitution cases is that "something has gone wrong or not the way it was planned or certainly not enough thought was given to it." 2000 PROCEEDINGS, supra note 14, at 229.

65. See Hanoch Dagan, Mistakes, 79 TEXAS L. REV. 1795, 1809-36 (2001) (analyzing the incentives generated by rules for restitution based on mistaken payment). See generally RICHARD A. POSNER, ECONOMIC ANALYSIS OF LAW 114-21 (5th ed. 1998) (discussing possible responses by contracting parties to mistakes and risks); Peter Huber, Mistaken Transfers and Profitable Infringements of Property Rights: An Economic Analysis, 49 LA. L. REV. 71 (1988) (examining incentives under different legal rules governing recovery for money, goods, and services transferred by mistake).

Consider, for example, claims for restitution of mistaken payments in the context of large wire transfers among banks. See, e.g., Gen. Elec. Capital Corp. v. Cent. Bank, 49 F.3d 280, 286 (7th Cir. 1995) and Banque Worms v. BankAmerica Int'l, 570 N.E.2d 189, 191 (N.Y. 1991) (both holding that when sender mistakenly sends funds to recipient (who is owed a debt by sender), the "discharge for

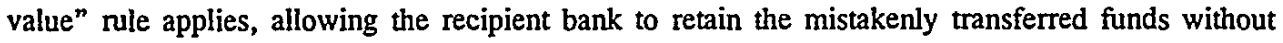
showing detrimental reliance). In a typical case, Bank $A$, acting for a depositor, mistakenly transfers funds to Bank $B$, a creditor of the depositor, and Bank $B$ applies the funds to the depositor's debt. In the cases cited, the courts applied the defense of "discharge for value" to hold that Bank $B$ was not 
all restitution cases involve mistakes. The coordination benefits of rules may be substantial in situations of borderline fraud, coercion, or officiousness-circumstances in which at least one actor is aware of the facts and can be expected to respond to likely legal consequences of his acts.

Another way in which the field of restitution might be defined is by reference to a prevalent (if not exclusive) feature of restitution claims: gain obtained by the defendant, usually at the plaintiff's expense. ${ }^{66}$ Applying this definition, the scope of the principle of unjust enrichment, and therefore the domain of individualized decision making, would include all instances of liability based on defendants' gains. Accordingly, courts deciding gain-based claims would have a special license to depart from rules when the rules produced unsatisfactory results. The question then becomes, is there anything in the nature of gain-based claims that makes them especially good subjects for judicial authority to vary the outcomes of rules case by case?

There are reasons to distinguish between benefit and harm as bases of legal liability. ${ }^{67}$ A regime that relied on liability for benefits received rather than liability for harm caused as the primary means of resolving disputes would face serious difficulties. Suppose, for example, that as a general matter, those who acted reasonably toward others were entitled to claim the benefit that their reasonable conduct conferred, while those who acted unreasonably would have no claim. Because legal claims would arise only when no harm was done, there would be difficulties in locating the baseline of unacceptable behavior above which the actor could assert a

liable to retum the mistaken payment. Andrew Kull makes a persuasive argument that this result is wrong, because it shifts risks that were deliberately assumed by the creditor bank to a bank that did not deliberately assume the risk, as a result of a clerical error. See Kull, stupra note 6, at 1237-40. Kull suggests, however, that the courts erred because they paid insufficient attention to the "balance of equities" between parties. Id. at 1239 . This reference to individualized equity seems out of place. There are good reasons to define as reliably as possible the legal risks that attach to wire transfers; thus, Kull has not shown that rules are out of place, but only that the courts have chosen the wrong rule.

66. This is the primary basis for restitution named in the pending Restatement. See ALI DRAFT, supra note $5, \S 1 \mathrm{cmt}$. a (stating that liability in restitution is triggered by the receipt of a benefit). But see Wonnell, supra note 4 (making a plausible argument that all recognized restitution doctrines are really forms of liability for harm). Cf. Dawson, Restitution, supra note 4 (questioning whether restitution typically involves enrichment).

67. Economic analysis casts doubt on the existence of harm and benefit as distinct phenomena in the absence of legal entitlements. A pollution control device on a factory's smokestack reduces harm if nearby homeowners are entitled to be free of smoke; if they are not so entitled, the pollution control device confers a benefit. Once entitlements are fixed, however, the distinction makes sense. See Wendy J. Gordon, Of Harms and Benefits: Torts, Restitution, and Intellectual Property, $21 \mathrm{~J}$. LEGAL STUD. 449, 451-52 (1992) (arguing that a stable baseline solves the difficulty); Donald Wittman, Liability for Harm or Restitution for Benefit?, 13 J. LEGAL STUD. 57, 58-59 (1984) (arguing that the current understanding of the symmetry between harm and benefit is unsatisfactory). 
claim, and in identifying appropriate defendants. ${ }^{68}$ Moreover, assuming that most people conform to legal standards, the costs of administering a system that allowed claims by those acting correctly would be far higher than the costs of a system that imposes liability on those who depart from the standard. ${ }^{69}$ The various problems of gain-based claims, however, are best understood as reasons for limiting the scope of gain-based liability and relying on harm-based liability for most incentive purposes. They do not explain why such recovery as there is for gain should be less rule-bound than recovery based on harm.

A further circumstance that might be thought to justify individualized decision making in cases of gain-based liability is that the gains at issue typically are not bargained for, and therefore are difficult to verify and measure. ${ }^{70}$ The subjective value of harm is also difficult to measure, but when one's resources are harmed we can be fairly confident that the victim has suffered some subjective loss of value. In contrast, when one's resources are objectively enhanced, there is no certainty of subjective benefit. $^{71}$ Again, however, this seems a reason to limit awards of restitution, rather than to evaluate gain-based claims on a case-by-case basis. ${ }^{22}$

It might be argued that when courts evaluate the claim that one person has gained at another's expense, not only do they face valuation problems, but they inevitably are drawn into questions of proportionality. Consider, for example, a notorious restitution problem-the problem of mistaken improvement of property-in which $A$ accidentally builds a structure on $B$ 's vacant lot. In this situation, standard property law holds that $B$ is the owner of the new structure. The question for restitution law is whether $A$ is entitled to restitution for the value he added to $B$ 's lot. ${ }^{73}$

68. See Gordon, supra note 67 , at 456 ; Wittman, supra note 67 , at 64 .

69. See Gordon, supra note 67, at 456; Wittman, supra note 67 , at $62-63$ (both discussing the issue of administrative costs). Wittman also suggests that subsidizing actors who cause no harm may result in inappropriate decisions about entry and activity levels. Wittman, supra note 67, at 67-71. In some cases, however, subsidizing activities with positive externalities may prove efficient. See id. at 71-73.

70. See Saul Levmore, Explaining Restitution, 71 U. VA. L. REV. 65, 69-72, 74-79 (1985) (making clear that there are two distinct problems affecting valuation in the absence of a bargain-the relative ineptitude of courts in fixing objective values and individual differences in taste and ability to pay). Levmore treats these problems together under the heading "wealth dependency." Id. at 74.

71. See id. at 77 (noting that a "homeowner is unambiguously worse off when his usable water is polluted but not unambiguously better off after a forced purchase of additional pure water").

72. Levmore argues that the problem of wealth dependency and the desire to encourage voluntary bargaining explain the pattern of restitution cases in a negative way: courts tend to allow restitution claims in contexts that do not raise serious problems of wealth dependency and market avoidance. See id. at 74-82.

73. Compare Isle Royale Mining Co. v. Hertin, 37 Mich. 332 (1877) (denying recovery) with Somerville v. Jacobs, 170 S.E.2d 805 (W. Va. 1969) (giving the land owner a choice either to pay the 
In mistaken improvement cases, doubts about the subjective value of the benefit to $B$, together with $B$ 's lack of consent and the possibility that $A$ was careless, counsel against an award of restitution. Yet, if the court denies the remedy, $A$ will pay a large price for his mistake and $B$ will almost certainly obtain a significant windfall. In these circumstances, proportionality becomes critically important: if the value of the plaintiff's improvements overwhelms the value of the defendant's unimproved property, the risk of a subjective loss to the defendant is minimal and hardship to the plaintiff looms large. As a result the choice of outcome depends on how much is too much along a continuum with no natural cutoffs or tipping point. A determinate rule fixing a cut-off ("Hold for the improver if the value added is more than twice the original value of the property") is unacceptable because courts are reluctant to draw arbitrary lines in the manner of a legislature. Therefore, the argument might run, cases of this kind are best judged individually. ${ }^{74}$

For several reasons, this argument cannot support the claim that courts deciding gain-based claims should be less deferential to rules than they would be in other contexts. First, not all gain-based claims involve questions of subjective value and proportionality. In some cases, as when money is paid by mistake, the value of the benefit is not in question. ${ }^{75}$ In other cases, the court is not concerned with the risks placed on the defendant or the extent of the plaintiff's loss, because the object of the restitution remedy is to deter whatever action the defendant took to obtain the gain. ${ }^{76}$ Second, judgments of proportionality are not unique to restitution. For example, a situation parallel to the problem of restitution to mistaken improvers arises in property law, when courts must decide when an improver has obtained title by accession. ${ }^{n}$ Finally, individualized decision making may not be the best response to concerns about valuation and the propriety of line-drawing. In cases of mistaken improvement, the most promising solutions have been creative remedial devices designed to test subjective values, rather than fact-specific decisions. ${ }^{78}$

value of the improvement or to convey the land for its unimproved value). See generally RESTATEMENT, supra note 2, § 42; Kelvin H. Dickenson, Mistaken Improvers of Real Estate, 64 N.C. L. REV. 37 (1985).

74. See ALI DRAFT, supra note $5, \S 10 \mathrm{cmt}$. a ("[T]he degree of hardship to the owner ... depends entirely on the circumstances of the particular case and on the nature of the remedy selected.").

75. See, e.g., RESTATEMENT, supra note 2 , $\$ \$ 15-38$ (discussing mistaken payments).

76. See id. $\S \S 1128-1138$ (addressing benefits acquired tortiously); id. §§ 190-200 (addressing breach of fiduciary duty).

77. See, e.g., Wetherbee v. Green, 22 Mich. 311 (1871) (denying replevin and limiting owner to damages when improver had mistakenly converted timber worth $\$ 25$ and made it into barrel hoops worth $\$ 750$ ).

78. For example, some courts have resolved mistaken improvement cases by overriding normal accession rules and permitting the improver to remove the improvement from the land. The purpose 
In short, restitution encompasses a wide range of subjects, many of which appear to be no more or less suited to individualized decision making than the subject matter of other fields of law. It is possible that I have overlooked some common characteristic of restitution claims that makes restitution a particularly appropriate domain for equity. Unless some such characteristic-a characteristic that is both unique to restitution and present in all restitution cases-can be identified, however, interpretation of the principle of unjust enrichment as a source of special authority for judges to depart from rules within that domain is unjustified. ${ }^{79}$ This is not to say that there should be no corrective equity in the field of restitution, because guidance and coordination will sometimes give way to other objectives. But there is no apparent reason why judges should practice more equity here than in other areas of law.

2. Equity Across Fields of Law.-There remains one more way to interpret the principle of unjust enrichment as a source authority for judicial departure from rules in particular cases. At this stage of the analysis, we are still equating unjust enrichment with equity in the Aristotelian sense of case-by-case adjustments to outcomes of general rules. Rather than a license for equity within a limited domain, however, the principle of unjust enrichment might be understood as a more general source of authority for judges to vary the results of rules in any area of law.

On this view, whenever any rule of law produced a bad result in a particular case, the result could be reversed by a finding of unjust enrichment and an award of restitution. ${ }^{80}$ Restitution would not be conceived as a special domain of individualized justice, but as a vehicle used to accomplish individualized justice across fields of law. In effect,

of this remedy is not to allow the improver to spite the recipient, but to encourage the recipient to offer a settlement if indeed he values the improvement. See, e.g., Shick v. Dearmore, 442 S.W.2d 198 (Ark. 1969) (holding that plaintiff who accidently drilled water on defendant's land was entitled to remove well and restore property to original condition). A decree of this sort is equitable in the sense that it relies on remedial tools developed historically in equity, but does not represent equity in the Aristotelian sense.

79. A further difficulty with the view that restitution, defined as gain-based recovery, is a peculiarly appropriate domain for individualized justice is that gain by one person at the expense of another is a description that can be made to fit almost any human action. If so, it is pointless to characterize restitution, so defined, as a special domain for equity. See Wonnell, supra note 4, at 159 ("The coexistence of benefit and harm . . . is present in virtually all civil wrongs. For that matter, this coexistence obtains in virtually all human actions . . . .").

80. For example, in Riggs $v$. Palmer, regulating wills and the devolution of property would have given property to the testator's nephew, who had murdered the testator in order to obtain the property. The court altered the outcome of the statutes by imposing a constructive trust on the murderer in favor of other heirs. Riggs v. Palmer, 22 N.E. 188, 189-99 (N.Y. 1889). 
restitution remedies would take up the role played by the remedies granted by the Chancery court in the early period of the common law. ${ }^{81}$

The problem with a general equitable exception to legal rules is that the rules may become unreliable and their advantages, particularly their role in coordinating conduct, may be lost. Suppose, for example, that over a period of time, courts have established a rule holding that there can be no liability for services performed without request or consent. ${ }^{82}$ The primary social function of this rule is to provide coordination: consent provides a boundary that allows both providers and recipients of services to know what to expect. ${ }^{83}$ The rule may have recognized exceptions, such as an exception for medical services rendered in an emergency, ${ }^{84}$ but otherwise it is decisive.

Now suppose further that the rule is altered by adding a general equitable exception: there can be no liability for services rendered without request or consent, unless there is good reason to allow recovery. At this point, despite the appearance of a rule, there is no constraint on decision making. ${ }^{85}$ A good reason to allow recovery presumably is one that outweighs the reasons to deny recovery, therefore judges (and actors anticipating what judges will do) must evaluate the various reasons for or against recovery, all things considered. If the judges' conclusions were always correct, and actors correctly predicted those conclusions, there would be no cause for concern. But it must be assumed that both judges and actors will err; otherwise, there would be no need for rules at all. Accordingly, if the unsolicited-services rule is qualified to allow an exception whenever there is good reason for an exception, there is no way to predict what other actors will do and what consequences will follow.

Perhaps the equitable exception could be limited to egregious cases: no liability without request or consent unless there is a very strong reason

81. See supra notes $39-47$.

82. This could be viewed either as a rule of restitution or as a nule of contract law. In effect, the first Restatement takes this position, with a number of exceptions. See RESTATEMENT, supra note 2, $\S 41$ (no restitution for services performed by mistake in a broad range of settings), $\S 112$ (no recovery for services rendered voluntarily without consent), $\$ 40$ (certain situations in which restitution is allowed for services performed by mistake), $\S 113-117$ (certain situations in which restitution is allowed for services performed voluntarily without consent).

83. Substantively, the rule may also reflect the value placed on liberty; but in this case the principal effect of casting the rule in determinate, rule-like form is to coordinate conduct.

84. See RESTATEMENT, supra note $2, \S 116$ (1937) (preservation of another's life or health).

85. I am assuming, contrary to logic but consistent with experience, a willingness on the part of actors and judges to follow the terms of the rule, against their own contrary judgment or impulse, in the absence of an equitable exception. For discussion of the irrationality of obedience to rules, see ALEXANDER \& SHERWIN, supra note 34, ch. 4; HURD, MORAL COMBAT, supra note 37, at 69-94; Hurd, Challenging Authority, supra note 38, at 1611 ("For it appears that to act because one has been told to, and not because the balance of reasons favors such action, is definitional of irrationality."). 
to allow recovery. This is more consistent with the way in which courts have in fact managed equitable exceptions to rules. Yet even this modest version of equity leaves rules unstable. The rule may now have some constraining effect if the judge believes that the reason for an exception is insufficiently strong; however, the possibility of error on the part of both judges and actors in anticipating what judges will do continues to undermine coordination. ${ }^{86}$

This is a general problem for law. Neither pure equity nor strict law without equity is satisfactory. As a result, courts have always maintained an uneasy compromise between rules and equity, often by shifting between the two. Proof of this tension between rules and equitable exceptions can be seen in the history of the Chancery court, which began as a source of relief from harsh results produced by strict rules of common law, but ultimately developed determinate rules of its own. ${ }^{87}$

The important point is that, whatever allowance is made within a legal system for equitable correction of rules, there is no evident reason why the law of restitution should provide the vehicle for equity. Restitution doctrine performs useful functions, for example by laying out reasonably clear guidelines for the consequences of mistaken payments. A conflation of restitution with individualized decision making will both impair the practical value of doctrinal rules governing restitution and obscure the trade-off between rules and particularized justice that runs through fields of law. Conflation of restitution and corrective equity also favors those parties who can style themselves as restitution plaintiffs, seeking to recover a gain obtained at their expense. ${ }^{88}$

It might be argued that restitution provides a means of introducing equitable adjustments into law without a significant loss of the benefits of determinate rules, simply because restitution is not well understood by the world at large. ${ }^{89}$ In other words, it might be possible to announce clear,

86. See ALEXANDER \& SHERWIN, supra note 34, ch. 4 (explaining why rules are undermined when treated as rules of thumb, subject to case-by-case exceptions).

87. See supra text accompanying notes 39-47.

88. It may in fact be possible to characterize most of the unwanted outcomes of most rules as instances of unjust gain at another's expense, but this will sometimes entail an artificial definition of gain, loss, or both. For example, consider Vickery v. Ritchie, 88 N.E. 835 (Mass. 1909), in which an architect fraudulently caused a builder and a property owner to sign agreements stating two different prices for the construction of a Turkish bathhouse. As a result, the builder performed work valued at $\$ 33,500$, expecting to be paid $\$ 33,721$. Meanwhile, the owner expected to pay $\$ 23,200$, and the value of his property was increased by $\$ 22,000$. The court allowed the builder to claim $\$ 33,500$ as restitution. Id. at 835-36. Assuming this result represents an equitable exception to the normal requirement of consent or request, it is a stretch to say the owner obtained a $\$ 33,500$ gain at the builder's request. Compare Dawson, Restitution, supra note 4, at 594-97 (arguing the result was fair, though declining to rest it on unjust enrichment), with Kull, supra note 6, at 1210-12 (arguing that the result was wrong).

89. See Kull, supra note 6, at 1195 ("To put it bluntly, American lawyers today (judges and law professors included) do not know what restitution is."). 
unqualified rules of law, and at the same time modify those rules at the point of application through little-known restitution remedies. If the law of restitution is sufficiently obscure, the public would perceive only the announced rules, not realizing that they are qualified by the possibility of equity in particular cases. Actors would then rely on the rules to coordinate their conduct and order their affairs, without discounting the rules' value to reflect the hidden exception available through restitution..$^{90}$

To accept this argument, however, is to endorse a form of deception in law. Legal rules carry the implicit representation that they will be enforced according to their terms; a general equitable exception, kept separate and obscure under the doctrinal cover of restitution, contradicts that representation. Not only is this state of affairs morally and politically suspect, but it is also difficult to maintain in the long run. ${ }^{91}$

Thus, leaving unresolved the basic question of how much equity a legal system should allow, it seems unwise to interpret unjust enrichment as a general source of authority for judges to avoid the undesirable consequences of rules.

\section{B. Unjust Enrichment As a Legal Principle}

Another sense of the word equity is simply that which is fair and just, in conformity with morality. The law of restitution can be linked to equity in this sense by interpreting unjust enrichment as a "legal principle," which refiects the moral tenet that one person should not obtain unfair advantage at another's expense and which operates as a decisional standard in contestable cases.

This understanding of the principle of unjust enrichment relies on a particular conception of the nature of law and judicial decision making, a conception that has been defended most notably by Ronald Dworkin.?

90. See Gerald J. Postema, Bentham and the Common LAW Tradition 403-08, 448-52 (1986) (discussing Bentham's plan to promulgate a code of laws but allow judges to adjudicate on other grounds); Meir Dan-Cohen, Decision Rules and Conduct Rules: On Acoustic Separation in Criminal Law, 97 HARV. L. REV. 625, 630-36 (1984) (suggesting the possibility of "selective transmission" of strict conduct rules, accessible to the public, and more lenient decision rules, known only to judges). A similar pattem of "acoustic separation" can be found in the relation between legal rules and "equitable defenses" applicable only to the relatively arcane remedies granted by equity courts. See Emily L. Sherwin, Law and Equity in Contract Enforcement, 50 MD. L. REV. 253, 300-14 (1991).

91. See SHERWIN \& AlEXANDER, supra note 34, at 4-54 to 4-59; Larry Alexander \& Emily Sherwin, The Deceptive Nature of Rules, 142 U. PA. L. REV. 1191, 1212-22 (1994).

92. Dworkin's conception of law, and of the role that legal principles play in judicial decision making, is set out in RONALD DWORKIN, LAW's EMPIRE 228-58 (1986) [hereinafter DWORKIN, LAW'S EMPIRE] (analogizing the role of a judge making common law to that of a chain novelist who writes based both on the material that has been written before as well as on what his successors might want to add), and RONALD DWORKIN, TAKING RIGHTS SERIOUSLY 14-45, 81-130 (1977) [hereinafter 
Law, on this view, consists not only of rules announced by appropriate authorities, but also of background legal principles. Legal principles are principles constructed by judges from available legal materials such as cases and statutes, which interpret those materials in their best moral light, and which themselves possesses the authoritative status of law. The task of a judge faced with a hard case-one not firmly controlled by an existing doctrinal rule-is to survey the range of prior decisions in light of his own moral and political convictions and develop a principle that provides the most morally attractive justification that can be made to "fit" the majority of prior outcomes. ${ }^{93}$ The resulting legal principle is unlike a rule of law in that it may give way to contrary principles in a given case. However, it possesses legal weight, such that, to the extent it prevails over conflicting legal principle, it provides the judge with a standard from which to deduce correct outcomes in new cases. ${ }^{94}$ Thus, legal principles, even as judges discover them and apply them in new ways, count as law and form the basis for claims of legal right. ${ }^{95}$

Applying this analysis to restitution and unjust enrichment, the original Restatement of Restitution might be understood as stating an authoritative legal principle-that no one should be unjustly enriched-together with illustrative doctrinal consequences of that principle. A proponent of this view might characterize the process by which Seavey and Scott drafted the original Restatement as one of combining existing materials with moral judgment, and concluding from these sources that unjust enrichment is an active principle of law, capable of supporting an undetermined range of future decisions. In particular contexts, the principle forbidding unjust enrichment may compete with the principle that courts should not reward those who meddle officiously in others' affairs ${ }^{96}$ or the principle that

DWORKIN, TAKING RIGHTS SERIOUSLY] (discussing the development and application of legal rules and that courts decide "hard cases," to which no legal rule applies, by applying legal principles).

93. See DWORKIN, LAW'S EMPIRE, supra note 92, at 254-58 (summarizing decision making according to principle); DWORKIN, TAKING RIGHTS SERIOUSLY, supra note 92, at 110-23 (discușsing the requirement of "fit").

94. See DWORKIN, TAKING RIGHTS SERIOUSLY, supra note 92, at 24-28, 35-36 (distinguishing rules and principles and describing the "dimension of weight").

95. The authoritative status of legal principles is central to Dworkin's conception of the nature of law and legal decision making. In Dworkin's view, the existence of legal principles means that in every case that may arise, there is a predetermined set of legal rights and, correspondingly, a legally correct outcome. This in turn enables the legal system to provide its subjects with a form of fair and equal treatment that Dworkin calls "integrity." See DWORKIN, LAw's EMPIRE, supra note 92, at 227 (describing "integrity" as "insist[ing] that the law-the rights and duties that flow from past collective decisions and for that reason license or require coercion-contains not only the narrow explicit content of these decisions but also, more broadly, the scheme of principles necessary to justify them."); DWORKIN, TAKING RIGHTS SERIOUSLY, supra note 92, at 81, 87-88 (describing the "rights thesis" and the requirement of "articulate consistency.").

96. See Owen v. Tate, [1976] 1 Q.B. 402 (Eng. C.A. 1974) (finding a transfer officious); RESTATEMENT, supra note $2, \S 2$ (rejecting claims by those who have acted officiously). 
people are at liberty to compete fairly with others. But if a court determines that the principle of unjust enrichment has greater weight than its competitors in a newly arisen case, it provides a legal ground for deciding in favor of the claimant. ${ }^{97}$

This interpretation of unjust enrichment, as a morally inspired and substantively equitable background principle of law that can serve as a decisional standard, differs from equity in the Aristotelian sense. The results that courts derived from a legal principle prohibiting unjust enrichment would not be individualized exceptions to rules. Rather, they would be generally applicable conclusions of law, to be added to the body of legal materials.

The cases of Kossian v. American National Insurance $\mathrm{Co}^{98}$ and Sharp v. Kosmalski9 ${ }^{99}$ appear in a different light if the principle of unjust enrichment is interpreted as a legal principle. If, as in Kossian, a court concludes that it is unjust for a mortgagee to retain insurance proceeds while a contractor who repaired the harm goes unpaid, then the principle forbidding unjust enrichment gives the contractor a legal right to recover and provides the court with authority for restitution. If, as in Sharp, a court concludes that a defendant has behaved unjustly by keeping the plaintiff's gifts (albeit in a manner not recognized as wrong by tort law or the rules governing gifts), then the principle forbidding unjust enrichment provides legal authority for corrective justice, through an order requiring the defendant to return the gifts.

The idea that law includes not just rules but also legal principles that determine the outcomes of hard cases has been criticized (and defended) on a variety of practical and jurisprudential grounds. One forceful objection to legal principles is that they build the errors of prior decisions into current decisions in new areas, through the requirement of "fit." Adherence to fixed rules of precedent has the same effect, but rules are more limited in scope and have compensating advantages for guidance and coordination that a set of competing principles cannot provide. ${ }^{100}$

A legal principle prohibiting unjust enrichment, however, does not suffer from this difficulty; it operates at much too high a level of generality for entrenchment of past errors to be a problem. Rather, what makes

97. This is not the view expressed by the Reporters of the original Restatement, Warren Seavey and Austin Scott. See supra text accompanying notes 8-9. However, it may be what some proponents of a link between restitution and equity have in mind. See 1 DoBBS, supra note $9, \S 4.1(2)$, at 371 (noting that unjust enrichment "has the potential for resolving new problems in striking ways"); BEATSON, USE AND ABUSE, supra note 9, at 1-2 (evaluating enactment of the principle of unjust enrichment); Nicholas, supra note 9, at 609 (describing unjust enrichment as a gap-filler).

98. 254 Cal. App. 2d 647 (1967). See supra text accompanying notes 20-23.

99. 351 N.E.2d 721 (N.Y. 1976). See supra text accompanying notes 24-30.

100. See Larry Alexander \& Ken Kress, Against Legal Principles, 82 IowA L. REV. 739, 741 (1997); Larry Alexander, Striking Back at the Empire: A Brief Survey of Problems in Dworkin's Theory of Law, 6 LAW \& PHIL. 419, 420-21 (1987). 
unjust enrichment both powerful and dangerous when interpreted as a legal .principle is its open-endedness. Unjust enrichment is a highly abstract and morally charged idea, capable of accommodating many contestable views of corrective and distributive justice. ${ }^{101}$ As a result, it invests judges with a tremendous amount of power.

A legal principle forbidding unjust enrichment may also tend to undermine more concrete doctrinal rules that define and limit occasions for restitution. A legal principle must meet a "threshold" requirement of fit with existing legal material, meaning that it must be consistent with some, but not all, prior statutes and decisions. ${ }^{102}$ At first glance, the requirement of fit seems protective of existing doctrine. Yet, because the fit need not be perfect, it leaves judges free to disregard a certain number of prior decisions or announced rules that conflict with a favored principle. Further, the inquiry into fit extends to all legal material, so that a principle that contradicts a fairly direct precedent might still be justified by the combination of its moral virtue and its fit with decisions in other areas of law. ${ }^{103}$ Ultimately, the principle, rather than the rules, is the source of

101. Concern over the vagueness and breadth of unjust enrichment led English courts to retreat from Lord Mansfield's broad statements in Moses v. Macferlan, 2 Burr. 1005, 97 Eng. Rep. 676 (K.B. 1760), and, for a period of time, to be very strict in their reading of restitution precedents. See DAwSON, supra note 3, at 15-21 (discussing Moses v. Macferlan). In 1922, Lord Justice Scrutton stated that "the whole history of [quasi-contract] has been what I may call a history of well-meaning sloppiness of thought." Hoit v. Markham, [1923] 1 K.B. 504 (Eng. C.A. 1922).

Christopher Wonnell has argued that the principle of unjust enrichment should be abandoned in favor of four more specific principles that explain the various instances of restiution recognized by courts and the Restatement. These are, roughly: (1) in the case of a clear wrong, courts should require disgorgement of profits as a second-best remedy when compensation is not feasible; (2) in the case of a "partial divestiure" of property, in which there is no voluntary transfer of rights, courts should provide a cost-based remedy to the transferor; (3) in the case of a deliberate invasion of clearly defined property rights, courts should require disgorgement of profits to prevent circumvention of markets; and (4) when one party confers benefits on another, for which the recipient would have contracted but for high transaction costs, courts should mimic the missing contract through a cost-based remedy. See Wonnell, supra note 4, at 191-219. The principles Wonnell proposes could be conceived of either as rules or as weighted legal principles, operating at a more concrete level than the principle of unjust enrichment.

102. See DWORKIN, LAW'S EMPIRE, supra note 92 , at 230-31, 237-39, 245-51 (discussing the requirement of "fit"); DWORKIN, TAKING RIGHTS SERIOUSLY, supra note 92, at 116-22 (discussing "fit" and disregard of "mistakes").

Another point is that under Dworkin's formula, in which the judge applies the most morally attractive principle that meets the threshold requirement of fit, principles will always rest at the minimum acceptable level of fit, so as to maximize their moral attractiveness. This means that as more cases are decided, the set of authoritative legal materials will always be unstable, because each case decided according to a principle will increase the principle's level of fit with the entire body of law. At that point, the principle will exceed the threshold requirement of fit, which in turn allows judges to reject more existing materials in order to refine the principle and its moral virtue. See ALEXANDER \& SHERWIN, supra note 34 , at 8-32 to 8-33.

103. See DWORKIN, LAW's EMPIRE, supra note 92, at 250-51 (stating that decisions in the immediate vicinity have "local priority," but this priority is not absolute). John Mackie argued that this "holistic" approach to law will lead judges to treat cases they might otherwise view as settled by rules as "hard cases" that call for a novel judgment based on "principle." Therefore, the apparent 
the judge's decision, and, particularly when the principle is based on as broad an idea as unjust enrichment, this leaves doctrinal rules open to frequent revision.

The practical advantage of unjust enrichment as a legal principle is that it provides considerable authority for judicial shaping and revision of the law. For those who prefer a flexible body of law that can adjust rapidly to changing values, the capacity of a legal principle forbidding unjust enrichment to eliminate rules that are recalcitrant to the judge's best conception of justice will be attractive. It recalls Lord Mansfield's advances, in which he invoked principles of "natural justice and equity" to extend existing forms of action to radically new situations. ${ }^{104}$ At the same time, however, a legal principle forbidding unjust enrichment leaves rules insecure, and therefore means at least some loss of the coordination, guidance, and certainty provided by rules. And, as already noted, it places considerable power in the hands of judges.

Before reaching a conclusion on the merits of this interpretation of unjust enrichment, it may be useful to describe and compare a third alternative.

\section{Unjust Enrichment As an Organizing Idea for Common-Law Decision Making}

The third possibility is a modest one. Unjust enrichment can be understood in the way originally suggested by Seavey and Scott, as a common theme of the various doctrines grouped together as restitution. ${ }^{105}$ The law of restitution is organized around the idea of unjust enrichment, just as tort law is organized around unjust harm and contract law is organized around unjust breach of promise. In each case, the standard for judicial decision is not found in the principle of unjust enrichment itself; it is found in the particular doctrinal rules that have evolved, or may evolve through common-law processes, to carry out that idea.

On this third view of the principle of unjust enrichment, there is nothing especially equitable about restitution in comparison to other areas of law. Unjust enrichment does not provide authority for equitable exceptions to rules; courts operating in the field of restitution are no more

\footnotetext{
constraint of Dworkin's method is illusory, and construction and application of legal principles will in fact leave law less settled, certain, and determinate than would a positivist approach that respects canonical rules. See John Mackie, The Third Theory of Law, in RONALD DWORKIN AND CONTEMPORARY JURISPRUDENCE 161, 167-69 (Marshall Cohen ed., 1983). In reply, Dworkin conceded that it was at least possible that his approach "allows more 'settled' law to be challenged." Ronald Dworkin, $A$ Reply by Ronald Dworkin, in RONALD DWORKIN IN CONTEMPORARY JURISPRUDENCE, supra at 247, 273-75. See also DWORKIN, LAW's EMPIRE, supra note 92, at 265-66 (suggesting there may be no clear distinction between easy and hard cases).

104. Moses, 2 Burr. at 1012, 97 Eng. Rep. at 681.

105. See supra text accompanying notes 7-8.
} 
or less bound by rules than they would be in other areas of law. Nor does unjust enrichment provide authority for decision making according to the judge's best understanding of justice. Instead, its functions are descriptive and organizational.

It is sometimes suggested that an equitable approach to unjust enrichment is necessary for healthy development of restitution law. ${ }^{106}$ Whether this is true depends on one's view of how quickly and experimentally the legal development should proceed. For reasons discussed below, treating unjust enrichment as a descriptive and organizational principle rather than as a standard for decision may indeed have some inhibiting effect on judicial creativity. It will not, however, bring restitution law to a standstill.

To assess the effect of the third interpretation of unjust enrichment, one must ask how judges might develop new restitution law, without relying on unjust enrichment as a standard for decision. There are at least two possibilities: the method of analogical reasoning traditionally associated with common law and the positivist method of ordinary moral reasoning in the absence of governing rules. In each case, unjust enrichment can play a useful organizational role in judicial decision making, without serving as a source of authority for particular outcomes.

The traditional understanding of judicial decision making holds that judges reason by analogy to decide new cases and develop new rules. ${ }^{107}$ A judge faced with a problem that is not resolved by existing rules studies decided cases and, in a moment of intuition, distills from them a common theme, or "analogy-warranting rule," that captures relevant likenesses and differences. The judge then tests the analogy-warranting rule upward for consistency with higher-level justifications, and downward as applied to additional hypothetical facts. If the analogy-warranting rule survives these tests, the judge decides the problem case accordingly. ${ }^{108}$

106. Professor Dawson lamented the refusal of English judges in the later nineteenth century and twentieth century to extend the doctrinal boundaries of restitution law, which he attributed in part to a hostile reaction to Lord Mansfield's references to natural justice and equity, and in part to a "general condition" of extreme conservatism among English judges of the period. See Dawson, supra note 3, at 15-21 (noting that the English courts were more creative when granting equitable remedies); see also Beatson, Legislative Development, supra note 9, at 283 (remarking that the lack of judicial recognition of a change-of-position defense in the United Kingdom at a level "up to and including the Court of Appeal . . . may simply be a reflection of the difficulties the common law, as opposed to equity, has with apportionments"); GOFF \& JONES, supra note 9, at 13-15 (discussing the English courts' varying attitudes toward the principle of unjust enrichment).

107. For discussions of the analogical method, see generally EDWARD LEVI, AN INTRODUCTION TO LEGAL REASONING 1-6 (1949); CASS R. SUNSTEIN, LEGAL REASONING AND POLITICAL CONFLICT 62-100 (1996); Scott Brewer, Exemplary Reasoning: Semantics, Pragmatics, and the Rational Force of Legal Argument by Analogy, 109 HARV. L. REV. 925, 925-29, 962-63 (1996); Emily Sherwin, A Defense of Analogical Reasoning in Law, 66 U. CHI. L. REV. 1179 (1999).

108. For an excellent analysis of analogical reasoning as a (possible) form of logic, see Brewer, supra note 107 , at $962-63,1022-23$. 
The process of analogical reasoning just described is structurally similar to the process of constructing legal principles, yet it is likely to differ in practical effect. Decision according to legal principles, as described by Dworkin, is an ambitious "interpretive" process, in which the judge searches for principles that fit well within the entire body of existing law and are morally desirable when judged according to a fully developed theory of political morality. ${ }^{109}$ In contrast, traditional analogical reasoning relies more on intuitions or common understandings of similarity, and therefore typically operates at a lower level. ${ }^{110}$ As a consequence, Dworkin's process of interpretation is likely to produce more abstract principles, and to move the law farther and more quickly from prior decisions, than the traditional method of analogy.

The principle of unjust enrichment can assist in analogical reasoning without assuming the authoritative status of a legal principle. Unjust enrichment, viewed as an organizing principle rather than a decisional standard, provides a framework judges can use to sort and analyze cases. Thus, a judge may find it useful to consider whether new case $N$ is like or unlike decided case $D$ in terms of the type of enrichment obtained by the defendant, the type of loss suffered by the plaintiff, the connection between enrichment and loss, or the element of injustice involved. ${ }^{11}$ But this does not mean that unjust enrichment is itself an analogy-warranting rule, sufficient to link cases $N$ and $D$ and determine the outcome of $N$.

Suppose, for example, that a judge is considering whether a mortgagee who paid taxes on the mortgaged property in order to prevent foreclosure of a prior tax lien can recover the amount of the tax from the mortgagor. ${ }^{112}$ In prior cases, sureties who discharged debts they had guaranteed have been permitted to recover from the parties principally liable for the debts. ${ }^{113}$ The judge might reason by analogy that the present plaintiff should recover, based on an analogy-warranting rule to the effect that a payment made to protect one's own legal position is not officious in a way that justifies the beneficiary in retaining the benefit. ${ }^{114}$

109. See DWORKIN, LAW'S EMPIRE, supra note 92, at 254-58 (summarizing the construction of legal principles through the process of interpretation).

110. Cass Sunstein emphasizes this point. See SUNSTEIN, supra note 107, at 65-69 (envisioning analogical reasoning as a form of "incompletely theorized" agreement).

111. Peter Birks argues that the principle of unjust enrichment can be "downward-looking to cases" and nevertheless serve important functions. Specifically, such a principle supports a "shared and stable pattern of reasoning" that will help make restitution predictable, illuminates similarities among cases that will help to avoid "fragmentation" of restitution law, and provides an altemative to confusing terms such as quasi-contract. BIRKS, supra note 6, at 19-22.

112. See, e.g., E.B.M., Annotation, Right and Remedy of Mortgagee Who For Protection of His Security Pays Taxes on, or Redeems from Tax Sale of, Mortgaged Property, 123 A.L.R. 1248 (1939) (collecting cases).

113. See RESTATEMENT, supra note $2, \S 103 \mathrm{cmt}$. c, illus. 1.

114. See id. $\S 103 \mathrm{cmt}$. a; 3 PALMER, supra note $9, \S 10.5$, at $383-97$ (discussing payment of debts for reasons of self-interest). 
Unjust enrichment, functioning as a descriptive and organizational principle, can help to identify the similarity between the cases, because it clarifies the issue at stake (when retention of enrichment is warranted). But the actual basis for analogy-the analogy-warranting rule-is much more modest than a conclusion that both defendants were unjustly enriched.

The standard positivist account of legal reasoning rejects the method of analogy (as well as Dworkinian legal principles) and holds instead that judges should reach their decisions either by deduction from canonical rules or, when no rule applies, by ordinary moral reasoning. ${ }^{115}$ A positivist judge would first search for an applicable rule, and if no rule applied, would apply his best moral judgment to resolve the problem. To reach a moral judgment in the absence of a governing rule, he might form an intuition about the outcome of the case, test that intuition against more abstract moral propositions, and then refine both his concrete intuitions and his tentative abstract propositions until a satisfactory conclusion emerged. ${ }^{116}$ Prior decisions that appeared similar would serve as data about the world and about the judgments of past reasoners, but would not generate either analogies or authoritative legal principles. ${ }^{117}$ As in the case of analogical reasoning, the principle of unjust enrichment could help to sort intuitions and ideas by identifying issues for the judge to consider, but it would not serve as an authoritative decisional standard.

This method of decision making-moral judgment using unjust enrichment as an organizing principle-differs in two ways from decision making that works deductively from a legal principle forbidding unjust enrichment. The tendency of both these differences is to slow, but not stop, the pace of legal change.

First, according to the positivist account, moral reasoning comes into play only in the absence of a governing rule. As described in the previous section, decision making according to legal principles entails a limited deference to existing rules, in that principles must meet a threshold

115. See H.L.A. HART, THE CONCEPT OF LAW 123-32 (1961) (discussing the "open texture" of rules); Larry Alexander, The Banality of Legal Reasoning, 73 NOTRE DAME L. REV. 517, 518-19 (1998) (discussing reasoning in uncontrolled cases).

Despite its traditional association with the common law, some positivists have been quite hostile to analogical reasoning, arguing either that it is logically incoherent and flawed in outcome, or that it is really a disguised form of deduction from rules. See, e.g., RiCHARD A. POSNER, THE PROBLEMS OF JURISPRUDENCE 86-98 (1990) (describing reasoning by analogy as "an unstable class of disparate reasoning methods" and concluding that analogy is not a proper technique for weighing the value of precedent); SCHAUER, supra note 33, at 183-87 (suggesting that analogical reasoning is a form of deduction from rules); Larry Alexander, Bad Beginnings, 145 U. PA. L. REv. 57, 80-86 (1996) [hereinafter Alexander, Bad Beginnings] (arguing that analogical reasoning in law is flawed because it incorporates the mistakes of past decisions).

116. Moral judgment has been characterized as a process of reasoning to "reflective equilibrium." See, e.g., JOHN RAWLS, A THEORY OF JUSTICE 46-53 (1971).

117. See Larry Alexander, Bad Beginnings, supra note 115, at 74, 81 (discussing the roles of past judgments and reliance in legal reasoning). 
requirement of fit. Beyond the necessary minimum, however, judges constructing legal principles in hard cases may disregard inconsistent rules. Moreover, what appear to be easy cases-governed by rules-may be recharacterized as hard cases if the rule that governs them is contrary to a principle that is morally attractive to the judge and can be reconciled with a sufficient number of outcomes in other areas of law. ${ }^{118}$ A positivist approach may also allow for some overruling of obsolete or mistaken rules. Yet, under the positivist approach, overruling will tend to be an exceptional practice rather than a routine weeding of existing material that conflicts with moral judgment when the threshold of fit has been met. ${ }^{119}$

The second difference between moral reasoning in the absence of rules and decision making according to principle is psychological: judges who are aware that the sole source of authority for their decisions is their own moral judgment may be less likely to depart from the pattern of prior decisions in radical new ways. Decision making based on legal principles may initially appear more constrained, as a result of the requirement that principles must meet a threshold of fit with existing materials. Precedents have no such "gravitational force" in ordinary moral reasoning unless they state a directly applicable rule; in the absence of a rule their effect is limited to the moral force of any expectations they have generated. In fact, however, judges may be more cautious about striking out in new directions when they understand that their decisions are based directly on moral judgment than when they conceive themselves as discovering, and reasoning deductively from, principles that have the status of law. In other words, decision making will be more modest, and both errors and advances will be of lesser magnitude, if judges recognize that their conclusions in hard cases have no moral source.

For these reasons, Kossian v. American National Insurance Co. and Sharp v. Kosmalski may not have been decided as they were if the courts had confined themselves to the third, comparatively modest interpretation of unjust enrichment. Both cases moved far afield of established doctrine and, if regularized, would entail significant changes in the rules governing contracts, insurance, and gifts. Whether an interpretation that would inhibit decisions of this kind represents healthy conservatism or a failure of imagination depends on one's view of the meaning of justice, the importance of stability in law, and the wisdom of individual judges.

\section{Conclusions}

I believe it is a mistake to confuse restitution with equity in the sense of correction of the errors of rules in particular cases. There is nothing

118. See supra text accompanying notes $80-91$.

119. For an analysis of overnuling, see ALEXANDER \& SHERWIN, supra note 34, at 7-33 to 7-45. 
both unique to restitution and common to all subjects of restitution that justifies a greater disregard of rules than judges would countenance in other areas of law. Whatever level of equitable correction the legal system allows, it should be acknowledged so that its costs are recognized, rather than hidden within the relatively arcane subject of restitution.

As between unjust enrichment as a legal principle and unjust enrichment as a descriptive and organizational idea, the former encourages judicial creativity while the latter is more protective of established rules and likely to produce slower rate of legal change. My own instincts about the ideal pace of legal change, particularly in private law, are conservative. I am also wary of any single decisionmaker's innovative views on justice in human relations. Therefore, I prefer not to accord authoritative legal status to the principle of unjust enrichment. My main object, however, is not to argue about which of these interpretations is best, but to clarify the differences between them and the consequences that are likely to accompany them. 